\title{
The development and special aspects of Islamic finance in Europe at the present stage
}

\author{
Iryna Kurochkina $^{1}$ and Ulija Us $^{2}$ \\ ${ }^{1}$ PHD (Econ), International marketing Department, Alfred Nobel University 49000 Naberezhna \\ Sicheslavska str., 18, Dnipro, Ukraine, \\ ${ }^{2}$ PHD (Econ), Department of Banking, Simon Kuznets Kharkiv National University of Economics, \\ 61166, Nauka ave., 9-a Kharkiv Ukraine,
}

\begin{abstract}
The article is dedicated to the peculiarities and specificities of Islamic finance in Europe. We considered the prime tools of the Islamic economical system, historical aspects of the Islamic finance appearance in Europe. We also investigated the prospects of implementing and development of Islamic finance in Europe and in Ukraine.
\end{abstract}

The issues that concern the implementation of operating principles of Islamic financial institutions in the economic system of the country arise in the majority of the countries in these recent times. In contempt of the presence in more than 40 countries of the world, the greatest development of finance that was based on the principles of Islamic law was obtained in those countries where the legislative amendments were introduced to regulate new financial institutions and products, in a point of fact of Islamic banks and suitable Islamic financial instruments. The Industry leaders are Malaysia, UAE and Bahrain. Over recent years, considering a global migrant policies, the governments of Great Britain, France, Germany, along with CIS nations (Kazakhstan, Kyrgyzstan) have begun to develop Islamic finance in their countries [1].

Up to date, a clear definition of the concept of "Islamic finance" is almost absent in the economic and in legal sciences. It is linked with their key elements - the religious nature. In the constitutions of the countries in the East where Islamic finance is widespread foremost, it has been affirmed that religious sources of laws, inter alia the Quran and Sunnah, are the actions of a higher legal force.

The key and central principles of the Islamic economic doctrine, from the perspective of religious sources of law that properly distinguishes it from the traditional Western theory and practice, is the view of money.

The Sharia does not deny a consensual view of money as the means of circulation, a measure of value and a store of wealth. Islam shares the understanding of money as a human consciousness mechanism that was created to serve the economic needs of society, as an abstract category that is a social institution. The implication is that any product in certain circumstances may become an object of sale apart from money. They are considered only as a service, technical tool that does not have an intrinsic value.

Therefore, Islamic finance is a special type of money and debt relationship that do not contradict a traditional Muslim law (Sharia), between economic units that suffer a shortage of the financial resources, on the one hand, and they have spare cash, on the other hand.

Thus, the Islamic economy can be characterized as a system of management that is based on the norms and principles of Muslim law, that, however, does not mean that the 
activities of Islamic financial institutions are regulated solely by the rules of the Sharia. This is due to the fact that in the current context, geographically, the range zone of Islamic finance is not limited by the Arab world or Muslim countries. Islamic finance is used almost throughout the world as the local financial institutions, as well as internationally active banks and investment trusts. This type of "ethical finance" is the most widespread in Europe. With due time in Britain and France, where in early 2000s the issue about the development of Islamic finance was considered, some representatives of liberal parties and members of parliament sounded a note of warning that the development of Islamic banking facilities would mean the introduction of the Sharia in some European countries. However, after it became clear that the activities of Islamic banks and other Islamic financial institutions will be regulated by European law, all objections against the development of Islamic finance in Europe have been deposed.

The development of Islamic finance in Europe is influenced by at least two factors that at first sight, are not unrelated at all [2,3]:

a) the commitment for an enlargement of European financial business to Muslim countries and the willingness of Muslim exporters of gas and oil resources to invest net worth into European countries, including using diversification of financial products and target segments of the market of the large banking capital;

b) the change in the structure in the population of many European countries and the rapid increase in the share of the Muslim population in them that is becoming an essential feature of purchasing power on similar financial services.

Respectively of the second factor it is noteworthy that although the proportion of Muslims in the population of Europe increased from 4\% in 1990 to more than $7 \%$ in 2017, however, in the countries that received the largest number of migrants who profess Islam, their share in the population is still lower than in countries with native Muslim minorities. Thus, the share of Muslim population in France is less than $8 \%$, in Germany it is about $6 \%$, in the UK it is about 5\%, while in Bulgaria, every seventh inhabitant professes Islam [4].

In recent years, Muslims have played an increasingly active role in the economy of the European Union, recruiting the businessmen and skilled wage workers. Simultaneously, the energizing of the Islamic banks activities that remained stability during the Great Recession and became the ownable sources of investment. According to Thomson Reuters [4], in 2014, there were 15 Islamic banks, 13 Islamic windows in conventional banks, 19 other Islamic financial institutions or Islamic windows common investment foundations, 3 Islamic insurance companies out of 1,143 Islamic financial organizations in the world, immediately in the European Union. The share of Islamic banking in universal European bank assets produced $0.15 \%$ at the beginning of 2015 .

We should emphasize the following information in the capacity of elements in Islamic finance $[2,3,7,9]$ :

- system of prohibitions: Riba - prohibition of usury, Gharar - prohibition of uncertainty of contract terms, Maysir - prohibition of gambling and jobbing, Haram prohibition of participation in illegal activities;

- a set of financial institutions which activities involve the fundraising and investment of funds (banks and non-bank financial institutions);

- principles of financial business that was established in compliance with the Sharia: Musharakah - partnership or ownership, Murabahah - trade financing, Mudarabah - trust management, Mufavada - mutual trust, Ijara - an analogue of finance lease, etc.;

- Muslim tax system: Zakat is a tax that was intended to ensure a fair distribution of benefits, and Jizyah is a tax on people of different faith.

The fundamental difference between Islamic finance from the finance of the West is the presence of two key elements - the institutes: Riba and Zakat. Negative attitude towards usury came to Islam from Judaism, and it is also contained in the Gospel Book. The 
prohibition of usury is not a solely particularity of Islam, but it received the greatest development in it. The idea of social justice, equal distribution of funds among members of the religious community, relief aid and the downtrodden is a key to understand the Islamic financial system. However, the biggest unicity of Islamic finance lies precisely in the tax system that came from the religious duty of every believer to pay a tax in support of the poor men to distribute equitable public goods. The European researchers do not pay attention at that light, connecting Islamic finance and Islamic banking. It is important that the funds from Zakat are always required to the public pursue of the head of the religious community and can be spent only on the goals that are set by the Quran, that are "the orphans, the men, wanderers, beggars, etc." [6].

As relating to the first Islamic financial institutions in Europe, it should be noted that they appeared only in the late 1970s. By and by with the change in national legislation, fullfledge Islamic banks or so-called "Islamic windows" in conventional banks began to be created. So, in 1978, the Islamic Banking System (later it was renamed on Islamic Finance House Universal Holding) was created in Luxemburg and in December, 1982 the first Islamic insurance company Takafol (both for investors from the Gulf countries) was created. Upon an initiative of the royal family in Saudi Arabia, Islamic Banking System International Holding was reorganized in 1978 in Geneva, the first Islamic financial structure in the form of a company that is limited in the West, and in 1981, the financial group Dar al-Mal al-Islami Trust with the authorized share capital of 1 billion dollars. In the 1980-s this financial group created several Islamic banks in Europe, but most of them turned out to be unsuccessful, while some turned into investment companies [4]. In Switzerland, because of the existing legal restrictions, the first full-fledge Islamic bank was opened only in 2006 (Faisal Private Bank) [4].

Another project of Islamic banking in Europe was the acquisition of Investment Group in the UK of Hargrave Securities in 1982 by the Saudi-based Al-Baraka, an organization that had a license to conduct bank deposits. In 1987, when British law was changed and a demand for Islamic financial products had grown sufficiently, it was converted into Islamic bank.

The question of legal relations of regulation of Islamic finance in European countries is quite relevant, in other words, can religious norms (Sharia) exist as regulators in European countries?

In practice, for example, in Turkey, Egypt or in some EU countries in financial and banking law, the Islamic finance is considered as a separate case of an innovative financial product, that is void of its beginning of religious content. The emphasis is made on its financial security and on the fact that it does not create additional destabilizing effects on the financial system of subordinated jurisdiction. However, in view of historical and cultural stereotypes and value-based approaches in Europe, the question is whether Islamic finance needs additional or special measures to regulate, control or liberalize the activities in comparison with monetary institutions.

A rule of thumb states that qualification of a financial institution as an Islamic per se can create some additional complexities and burdens for it. In Muslim countries, it has a manifestation in the form of additional regulatory requirements and more severe punishment for non-compliance, in non-Muslim countries - the alert and unacceptability of this type of institutions still continues.

All this reduces the competitiveness and maneuverability of Islamic financial institutions in comparison with usual credit establishments and it creates additional restrictions on the ways in which profits are received. To mitigate the effects of negative factors, some regulators refuse the legal use of the concept of "Islamic finance" in the money and credit systems that are under of their control $[8,10]$. 
Speaking about the aspects of the development and existence of Islamic finance in Europe, in a point of fact the integration of Islamic banking into the economy of European countries, it should be reminded that it began its existence in its current form in the second half of the 20th century in Egypt as a single movement action of the Islamic idea of helping to the marginal population. Only one savings bank became both a kind of political demonstration and a reminder that faith in Islamic justice is alive and it requires action to improve the living conditions of the people and the return of religion as a powerful social societal glue.

The current conditions of social and economic evolution that are bitterly accelerating, continue to face the Arab countries with the challenges that threaten the loss of identity. To avoid this danger, they address insistently to their past in searching of roots that will keep them from being absorbed by the flow of mutual universalization. Other Arabic monarchies in Arabia succeeded in turning their faces to the national heritage; they found the mechanisms in the depths of their history that prevented them from getting lost in the traditions of the peoples and countries that followed the road of catching-up development and fell within the cultural and social pressure of globalization.

It is too early to talk about the future development and implementation of Islamic institutions in Ukraine, however, according to the authors, we shouldn't consider the aspects of the Islamic finance functioning from the point of view of demanding, that is widely seen, does not formulate offers in the information society, but rather on the contrary, follows it, and in the context of those economic benefits that will be able to obtain Ukraine from the development of Islamic financial products. One of the obvious benefits is the attraction of investments from the Middle East countries that is especially relevant in the current economic and financial crisis. Market appearance in Islamic financial institutions, at the core of which there is a lack of participation in distressed and speculative positions, can provide greater stability of the financial system of the country.

\section{References}

1. S. Krasnoliudska The Subjectivity of Islam in World Political Processes. Scientific notation. Pub. 37., Pg. 315 - 325 (2017)

2. R. Grassa, M. K. Hassan Islamic Finance in France: Current State, Challenges and Opportunities, Uluslararası İslam Ekonomisi ve Finansı Araştırmaları Dergisi, Pub. 1, P. 65 $-80(2015)$

3. Cl. Domat What Is Islamic Finance And How Does It Work? Available at: https://www.gfmag.com/topics/blogs/islamic-finance-faq-what-islamic-finance-and-howdoes-it-work

4. C. Hackett 5 Facts about the Muslim Population in Europe. Available at: http://www.pewrcsearch.org/fact-tank/2016/07/19/5- facts-about-the-muslim-population-ineurope/

5. Islamic Finance Development Report 2015. Global Transformation. 1CD - Thomson Reuters, 200 p. (2016)

6. I. Sobol Islamic Banking in the European Union Countries. European Integration Studies, no. 9, pp. 184-197 (2015).

7. A. Filonik Islamskie banki: zadachi na blizhaishee budushchee. Mirovaya ekonomika i mezhdunarodnye otnosheniya, vol. 61, no. 2, pp. 85-93. (2017).

8. A. Alharbi Development of Islamic Finance in Europe and North America: Opportunities and Challenges. International Journal of Islamic Economics and Finance Stuides, vol. 2, issue 3, pp. 109-136. (2016)

9. V. Malaev Opportunities for adapting Islamic banking products to the Russian legislative framework. Brics Law Journal Vol. IV, Issue 3, pp. 62-80 (2017) 
10. P. Abedifar, Sh. Ebrahim, Ph. Molyneux, A. Tarazi. Islamic Banking and Finance: Recent Empirical Literature and Directions for Future Research. Available at: https://halunilim.archives-ouvertes.fr/hal-010731852014. 